\title{
OfF-Shoring OF Production in European COUNTRIES
}

\author{
PAlcic, I.; BuchmeIster, B. \& HerzoG, N.V.
}

Abstract: This manuscript deals with analysis of several European countries in respect to off-shoring of production by their manufacturing companies. The analysis has been conducted in the scope of international project, coordinated by the famous German Fraunhofer institute, where an extensive survey was sent to thousands of manufacturing companies across Europe with the purpose of investigating manufacturing and innovation activities. This manuscript indicates results focused on the frequency of production off-shoring in European countries, target regions of offshoring activities and main motives for off-shoring and back sourcing activities. A special focus is on Slovenia as a new EU country that is becoming also extremely active in the field of off-shoring parts of its production.

Key words: production, off-shoring, back sourcing, manufacturing company, Slovenia, Europe
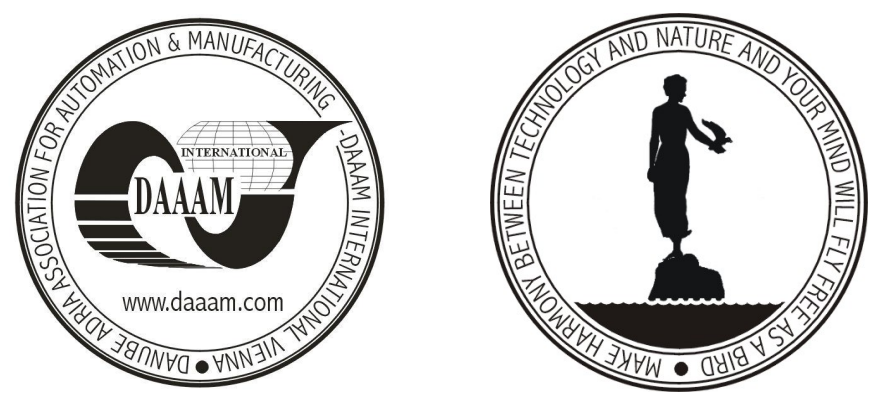

Authors' data: Ph.D. Ass. Prof. Palcic, I[ztok]; Dr. Sc. Buchmeister, B[orut]; Ph.D. Ass. Prof. Herzog, N[atasa] V[ujica], University of Maribor, Faculty of Mechanical Engineering, Smetanova 17, SI - 2000 Maribor, Slovenia, iztok.palcic@uni-mb.si, borut.buchmeister@uni-mb.si,natasa.vujica@uni-mb.si

This Publication has to be referred as: Palcic, I.; Buchmeister, B. \& Herzog, N.V. (2007). Off-Shoring of Production in European Countries, Chapter 09 in DAAAM International Scientific Book 2007, B. Katalinic (Ed.), Published by DAAAM International, ISBN 3-901509-60-7, ISSN 1726-9687, Vienna, Austria DOI: $10.2507 /$ daaam.scibook.2007.09 